\title{
Energetic performance of a portable cooking stove prototype for nine Eucalyptus species
}

\author{
André Luis CHRISTOFORO ${ }^{1}$, Everson Prado BANCZEK ${ }^{2 *}$, Juliana Mendonça FÁVARO ${ }^{3}$, \\ Leônidas KLUGER ${ }^{3}$, Alison MARGRAF ${ }^{3}$, Gilmara de Oliveira MACHADO ${ }^{3}$ \\ ${ }^{1}$ Departamento de Eng. Florestal, Universidade Federal de São Carlos, São Carlos, Brasil. \\ ${ }^{2}$ Departamento de Química, Universidade Estadual do Centro-Oeste, Guarauava, Paraná, Brasil. \\ ${ }^{3}$ Departamento de Engenharia Florestal, Universidade Estadual do Centro-Oeste, Irati, Paraná, Brasil. \\ *E-mail: edopradobanczek@yahoo.com.br
}

Recebido em fevereiro/2019; Aceito em julho/2019.

\begin{abstract}
Traditional cook stoves are energetic inefficient and demands high quantity of fuelwood. The aim of this study is to build a portable and efficient cooking stove based on the rocket stove technology that are projected to make better use of the energy released in combustion with lower fuel consumption and gas emission $\left(\mathrm{CO}_{2}, \mathrm{CO}\right.$ and $\left.\mathrm{SO}_{2}\right)$ than traditional stoves. Our prototype was built with recyclable metal materials and glass particles for thermal insulation of the combustion chamber. Nine Eucalyptus species were used as fuel. The cook stove evaluation occurred by the determination of thermal energy efficiency and fuel consumption, as well as estimated measurements of the thermal power and released gas amount $\left(\mathrm{CO}_{2}, \mathrm{CO}\right.$ e $\left.\mathrm{SO}_{2}\right)$. The average energy efficiency reached the range from $6.8 \%$ to $10.4 \%$, with a fuel wood consumption of about $0.1 \mathrm{~kg}$ for each 20 minute operation. Thermal power was from 94.1 to $326.0 \mathrm{~W}$, and the gas level was about $0.2 \mathrm{Nm}^{3} / \mathrm{kg} \mathrm{CO}_{2}, 0.02$ $\mathrm{Nm}^{3} / \mathrm{kg} \mathrm{CO}$, and $10^{-5} \mathrm{Nm}^{3} / \mathrm{kg} \mathrm{SO}_{2}$. The thermal efficiency of our prototype exceeded twice than the values of traditional stoves in Irati city that are range from 2.9 to $4.6 \%$, having the improved cook stove similar value of other world stoves. Our prototype presents a promising result in addition to offer a low production cost.
\end{abstract}

Keywords: rocket stove; biomass from planted forest; efficiency; gas emissions.

\section{Avaliação da qualidade energética de um protótipo de fogão à lenha portátil para nove espécies de eucalipto}

RESUMO: Os fogões tradicionais são energeticamente ineficientes e exigem alta quantidade de lenha. O objetivo desta pesquisa consiste na construção de um fogão à lenha portátil e eficiente, baseado na tecnologia rocket stove. Esses fogões são projetados para um menor consumo de lenha e uma menor emissão de gases $\left(\mathrm{CO}_{2}\right.$, $\mathrm{CO}$ e $\mathrm{SO}_{2}$ ). O protótipo foi construído com materiais metálicos recicláveis e vidro moído para isolamento térmico da câmera de combustão. Nove espécies de Eucalyptus foram utilizadas como combustível. A avaliação da qualidade energética do fogão ocorreu mediante a determinação da eficiência energética e consumo de combustível, bem como por estimativas da potência calorífica e quantidade de gases liberados na combustão $\left(\mathrm{CO}_{2}, \mathrm{CO}\right.$ e $\left.\mathrm{SO}_{2}\right)$. A eficiência energética média alcançou a faixa de $6,8 \%$ a $10,4 \%$, com consumo de combustível em torno de $0,1 \mathrm{~kg}$ para cada 20 minutos de funcionamento. A potência situou-se entre $94,1 \mathrm{e} 326,0 \mathrm{~W}$ e os teores de gases foram $0,2 \mathrm{Nm}^{3} / \mathrm{kg}$ de $\mathrm{CO}_{2}, 0,02 \mathrm{Nm}^{3} / \mathrm{kg}_{\text {de }} \mathrm{CO}$ e $10^{-5} \mathrm{Nm}^{3} / \mathrm{kg}$ para $\mathrm{SO}_{2}$. As medidas de eficiência do protótipo desenvolvido superaram medidas similares de fogões à lenha metálicos residenciais da mesma cidade de Irati, os quais se situam entre 2,9 e 4,6\%, tendo o fogão melhorado valor semelhante de outros países. Portanto, esse protótipo apresentou um resultado bastante promissor, além de oferecer um baixo custo de produção.

Palavras-chave: fogão melhorado; biomassa de floresta plantada; eficiência; emissão de gases.

\section{INTRODUCTION}

The modernization of the production and subsistence activities has emphasized the desire to create a self-sufficient energy rural society that produces virtually all that is required, being supplied by renewable energies with fuel wood from planted trees (CASTRO; CORTE, 1998; CASH et al., 2003).

Alternative energy sources as biomass, which cannot totally replace the petroleum, coal, natural gas and its derivatives, can contribute to reduce fossil fuel consumption that must play a central role in sustainable development (SOUZA et al., 2012).

Eucalyptus trees have emerged as one of more efficient fuelwood species applied for biomass energy, which is emphasized by Müller et al. (2005), Kidanu et al. (2005), Rockwood et al. (2008), Zanuncio et al. (2013), Gabrielle et al. (2013), Brand et al. (2014), among others.

For every six people worldwide, two use the fuelwood as the main energy source, particularly in households in developing countries, mainly for cooking and electricity generation processes. For every two harvested trees on the planet, one is directed used to energy generation (BRITO; CINTRA, 2004; BRITO, 2007; BRAND, 2010).

The biomass resources and the full range of technologies available for heat or electricity generation, both at small and large scales, can provide good opportunities for increased bioenergy production (SCARLAT et al., 2011). Brazil is a 
tropical country with widespread availability of lands with a high solar radiation. The condition stimulates the naturally grown of Forest. The biomass is abundant and can be widely used for energy purposes.

Wood for energy generation in Brazil has been historically linked to charcoal production following by residential, industrial and agricultural consumptions (SANTOS et al., 2012). The utilization of firewood for combustion processes in households has a substantial contribution, from a long-term view, to environmental impacts and sustainability (NOSEK et al., 2016).

According to data from National Energy Balance (EMPRESA DE PESQUISA ENERGÉTICA, 2018), fuelwood and charcoal has a significant share of $8 \%$ in energy production by resource, having $24,5 \%$ fuelwood consumption in residential sector, used mainly for cooking, and in a small scale, for house heating in temperate regions (ROSILLOCALLE et al., 2005; SEIXAS et al., 2006).

In the context of thermal energy consumption by households, firewood has an interesting participation equivalent to the liquefied petroleum gas $(26,5 \%)$, which according to Brito (2007) has been the natural replacement in most urban homes, and unlike fuelwood, it always has official incentive policies.

Biomass energy is traditionally used for direct combustion, burning mainly in cook stoves as fuelwood and less as charcoal. The variable efficiency of these stoves depends on the conversion rate of fuelwood energy in heat, technology, and construction type. Whereas gas and electric stoves can respectively present $57 \%$ and $50 \%$ of energy efficiency, firewood stoves can have these indexes in a range from $5 \%$ to 35\% (NOGUEIRA; LORA, 2003).

Popular in rural areas, most traditional cook stoves have a poor energy level, whereas they have a rapid and low efficient burning. These cook stoves produce large volatile and pollutant particles emissions, which could cause respiratory failures, eye diseases, chronic bronchitis, skin darkening, and cancer in human beings (NORTHCROSS et al., 2012).

Inefficient cook stoves enhance toxic gas emissions such as carbon monoxide, promoting a large fuelwood consumption. Furthermore, it promotes the increase of deforestation rates, once most of the firewood used in stoves does not come from planted forests, but from native forests (BORGES, 1994).

Due to disadvantages of the conventional firewood stoves, a more efficient one would provide an appropriate time for cooking food with a more complete and cleaner combustion, having lower cost and lower physical efforts to collect and stock the firewood. Finally, the use of fuelwood from planted forests and the lower fuel consumption for these stoves will contribute to decrease the deforestation rates in Brazil, especially in native tropical forests.

This research aimed to build a portable improved cook stove by the "rocket stove" technology and to evaluate its energetic quality (energy efficiency, thermal power, fuel consumption, and gas release) through nine species from the Eucalyptus forest planting located at the Forestry College at Irati city, Brazil.

\section{MATERIAL AND METHODS}

\subsection{Firewood stove}

The portable metal stove prototype studied here was built from scraps acquired in junkyard at Irati city in Paraná State,
Brazil. Thus, it was entirely manufactured from recyclable materials, fulfilling the goal of an easier accessibility for whole community.

The improved cook stove has $26,861 \mathrm{~cm}^{3}$, and a cylindrical wall in brass (copper and zinc) with a prismatic central tube of cast iron in "L" shape (combustion chamber). Figure 1 shows the firewood prototype and a real image of the built stove. The combustion chamber was thermally insulated with ground glass with a density of $0.8 \mathrm{~g} / \mathrm{cm}^{3}$. The volume of insulating space is $18,458 \mathrm{~cm}^{3}$.

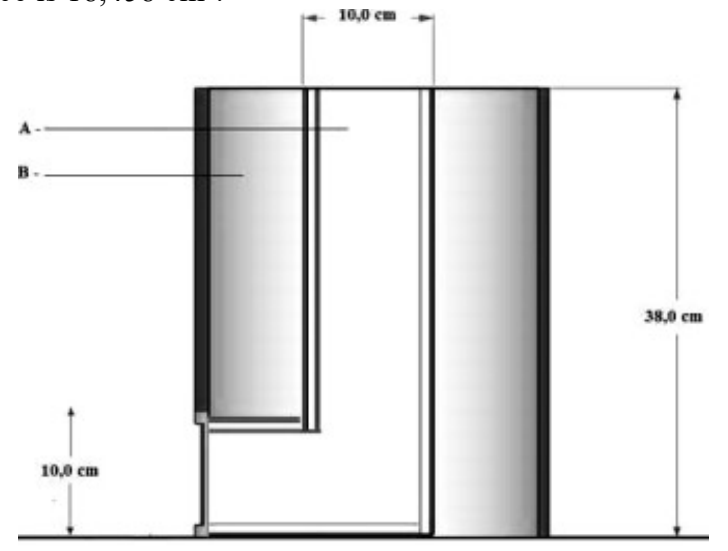

(a)

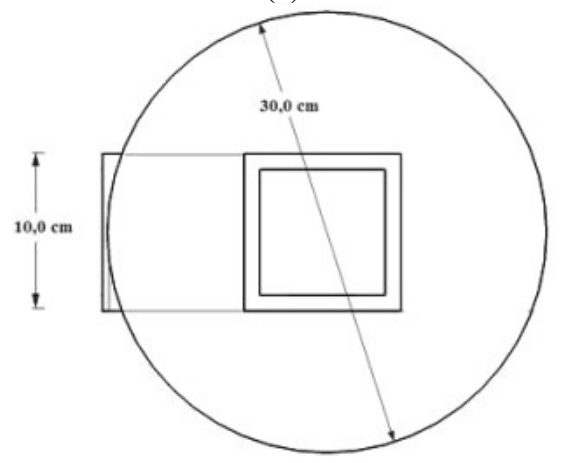

(b)

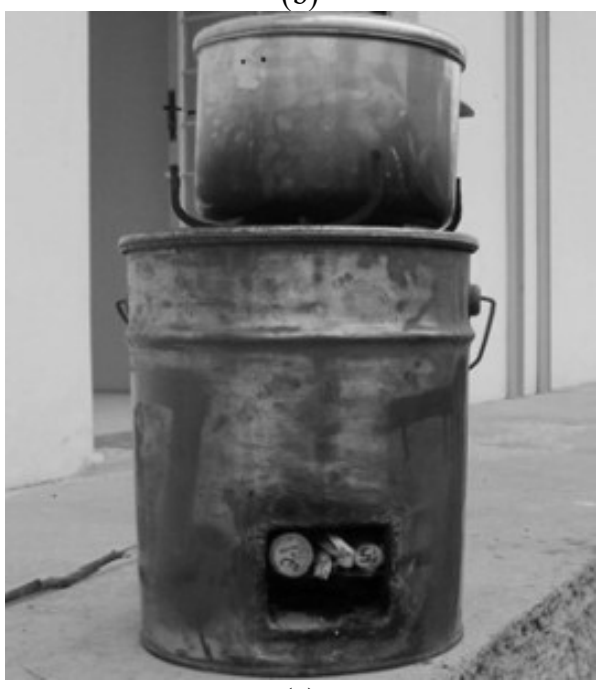

(c)

Figure 1. Cook stove prototype: (a) longitudinal section of the project, (b) transverse section of the project, and (c) real image.

Figura 1. Protótipo do fogão à lenha: (a) seção longitudinal do projeto, (b) seção transversal do projeto e (c) imagem real.

\subsection{Eucalyptus fuel}

The fuelwood used in this study was collected in an area with nine Eucalyptus species of TUME-Project (Forestry College of Irati), whose planting occurred in 2000. The 
evaluated species were E. citriodora, E. saligna, E. urophylla, E. grandis, E. urograndis, E. propinqua, E. pellita, E. camaldulensis and E. tereticornis. The experiment spacing is $2.0 \times 2.5$ meters, with planting area by species of $880 \mathrm{~m}^{2}$, with 176 trees in each block.

After the previous species identification, an exsiccate of each wood specimen was collected, constituted by branches containing only leaves, for evidential deposit in UNICENTRO herbarium (HUCO), at the Campus of Irati. Each species was identified with registration number (NR), trees of planting by species (NA), and the average value of wood moisture content (MC) with its standard deviation by species (Table 1). The tree samples collectors were indicated by their respective last names.

Table 1. Data of the species incorporated into the HUCO herbarium.

Tabela 1. Dados das espécies incorporadas ao acervo do herbário HUCO.

\begin{tabular}{lcccc}
\multicolumn{1}{c}{ Eucalyptus species } & NR & Collectors & NA & MC [\%] \\
\hline Eucalyptus propingua Deane \& Maiden & HUCO 5860 & Favaro & 61 & $14.3 \pm 0.2$ \\
Eucalyptus saligna Sm & HUCO 5857 & Margraf & 129 & $15.2 \pm 1.0$ \\
Eucalyptus urograndis & HUCO 5861 & Favaro & 88 & $13.8 \pm 0.1$ \\
Eucalyptus grandis Hill ex Maiden & HUCO 5862 & Favaro & 97 & $14.5 \pm 0.4$ \\
Eucalyptus citriodora Hook & HUCO 5858 & Margraf & 43 & $13.5 \pm 1.9$ \\
Eucalyptus urophylla S. T. Blake & HUCO 5859 & Margraf & 93 & $20.8 \pm 1.3$ \\
Eucalyptus pellita F. Muell & HUCO 5863 & Kluger & 54 & $13.7 \pm 1.0$ \\
Eucalyptus camaldulensis Dehn & HUCO 5864 & Kluger & 78 & $14.4 \pm 0.4$ \\
Eucalyptus tereticornis Sm & HUCO 5865 & Kluger & 89 & $14.2 \pm 0.3$ \\
\hline
\end{tabular}

$\mathrm{NR}=$ HUCO identifier; NA = sample number; $\mathrm{MC}=$ moisture content.

\subsection{Fuel evaluation}

Fuelwood was collected from branches arranged on the plot soil, with average diameters about 5 centimeters, and then, they were cut into small $\log$ s with a length of 30 centimeters. Each small $\log$ was numbered, weighed and packed in polystyrene boxes, avoiding the moisture content variation. Similarly to the approach of Machado et al. (2014), the determination of timber moisture content (dry basis) consisted in placing four small logs (representative in the sample) into the drying oven to $105^{\circ} \mathrm{C}$, with successive weighing to obtain constant mass.

The moisture content (MC) is given by the following equation (NBR 8112, 1986), where $\mathrm{m}_{\mathrm{i}}$ is the initial mass, and $\mathrm{m}_{\mathrm{d}}$ is the dry mass of the sample:

$$
\operatorname{MC}(\%)=100 \times \frac{m_{i}-m_{d}}{m_{d}}
$$

Higher heating value (HHV) was determined using the data from proximate analysis, through the following equation proposed by Parikh et al. (2005), where HHV is the higher heating value $\left(\mathrm{kcal} \mathrm{kg}^{-1}\right)$, FC fixed carbon (\%), VM volatile matter (\%), and A ash content (\%), Eq.02:

$\mathrm{HHV}=84.5104 \mathrm{FC}+37.2601 \mathrm{VM}-1.8642 \mathrm{~A}$

By means of the obtained Eq.02, according to following Eq.03 (DOAT, 1977; BRAND, 2010; CORTEZ et al., 2009), it was determined the lower heating value ( $\mathrm{LHV}, \mathrm{kcal} \mathrm{kg}^{-1}$ ), where $\mathrm{H}$ is the hydrogen content (\%):

$$
\mathrm{LHV}=\mathrm{HHV}-(600 \times 0.09 \mathrm{H})
$$

With the values of moisture content of firewood (Table 1) and the lower heating value (Eq. 03), it was calculated the net heating value (NHV, $\mathrm{kcal} \mathrm{kg}^{-1}$ ) from the Eq. 04, (BRAND, 2010), where MC is the moisture content (\%):

$$
\mathrm{NHV}=\operatorname{LHV}(1-0.01 \mathrm{MC})-(600 \times 0.01 \mathrm{MC})
$$

The firewood stove efficiency was calculated through the evaluation of the amount of heat absorbed by the water in a metal pan $\left(\mathrm{Q}_{\text {useful }}\right)$ and the amount of heat provided by the fuel $\left(Q_{\text {wood }}\right)$ (NOGUEIRA; LORA, 2003). Five repetitions were performed. Each test lasted 20 minutes and it consisted in to weigh certain amount of fuel, before and after the heating of 2 $\mathrm{kg}$ of water, without the boiling occurrence, in a metal pan with lid with 3 liters of capacity.

During each test, the temperature measurements were taken every 5 minutes (MACHADO et al., 2014). The lid was attached to a central shaft (axis) with a bottom propeller, allowing the mechanical agitation of water for temperature homogenization. After the preheating of the drying oven, the first test occurred with covered pan, except when the temperature measurements were realized. Thus, the pan was placed on the stove prototype only when the firewood had started its combustion process (MACHADO et al., 2014).

With the help of the basic function of Calorimetry in the Eq. 05, the useful heat absorbed by the water in the pan ( $Q_{u s e f u l}$, kcal) is calculated, where $\mathrm{m}_{\mathrm{H} 2 \mathrm{O}}$ is the mass of water to be heated $[\mathrm{kg}], \mathrm{C}_{\mathrm{H} 2 \mathrm{O}}$ is the specific heat of water $\left[\mathrm{kcal} \mathrm{kg}^{-1}{ }^{\circ} \mathrm{C}^{-1}\right]$, and $\Delta \mathrm{T}_{\mathrm{H} 2 \mathrm{O}}\left({ }^{\circ} \mathrm{C}\right)$ is the difference of temperature between the beginning and end of the test.

$$
\mathrm{Q}_{\text {useful }}=\mathrm{m}_{\mathrm{H}_{2} \mathrm{O}} \times \mathrm{c}_{\mathrm{H}_{2} \mathrm{O}} \times \Delta \mathrm{T}_{\mathrm{H}_{2} \mathrm{O}}
$$

After 20 minutes of each test, the fire was erased, and all the residual firewood inside the combustion chamber was taken to be weighed. To achieve a precise weighing, the burning residues were removed from the stove chamber and stored in sealed aluminum containers into polystyrene boxes for cooling, and then, they were weighed in a semi-analytical balance (MACHADO et al., 2014).

From the Eq.06, it was calculated the total heat provided by the fuel wood combustion $\left(\mathrm{Q}_{\text {wood }}, \mathrm{kcal}\right)$. In this expression $\mathrm{m}_{\mathrm{q}}$ is the mass of fuel consumed in water heating (difference between initial mass of firewood and combustion residual, $\mathrm{kg}$ ) and NHV is the net heating value of the firewood.

$$
\mathrm{Q}_{\text {wood }}=\mathrm{NHV} \times \mathrm{m}_{\mathrm{q}}
$$

Through the obtained results for useful heat and the energy released by burning of wood, it was calculated the efficiency of the cook stove (Ef, \%): 


$$
E f=100 \times \frac{Q_{u s e f u l}}{Q_{\text {wood }}}
$$

The calorific power of the portable stove $(\mathrm{Pf})$ was obtained by the Eq.08, which involves the burning time of firewood $(\Delta t)$. The other values were determined in previous calculations.

$$
P f=\frac{m_{q} \times N H V \times E f}{\Delta t}
$$

It was estimated by the improved cook stove the amount of the gases of carbon dioxide $\left(\mathrm{CO}_{2}\right)$, sulfur dioxide $\left(\mathrm{SO}_{2}\right)$, and carbon monoxide $(\mathrm{CO})$ released during burning process (MACHADO et al., 2014).

According to the scientific literature, the average quantity of $\mathrm{CO}$ released in the incomplete combustion of fuelwood in the cook stove is about $10 \%$ of the gas content of the carbon burning (JOSHI et al., 1989). With the values of elementary analysis from literature, it was possible to present a balanced equation for the firewood combustion, to determine the $\mathrm{CO}$, $\mathrm{CO}_{2}$ and $\mathrm{SO}_{2}$ contents released by burning of $1 \mathrm{~kg}$ of fuel, for each test, through the gases densities in the standard temperature and pressure, STP (MACHADO et al., 2014).

The elemental analysis was obtained by Cortez et al. (2009), dry basis, having 49\% carbon (C), 5.87\% hydrogen $(\mathrm{H}), 43.97 \%$ oxygen $(\mathrm{O}), 0.3 \%$ nitrogen $(\mathrm{N}), 0.01 \%$ sulfur $(\mathrm{S})$ and $0.72 \%$ ashes (A). If all carbon in the fuel reacts during the combustion is assumed, producing only $\mathrm{CO}_{2}$ and $\mathrm{CO}$ (with conversion of $90 \%$ of carbon in $\mathrm{CO}_{2}$ and $10 \%$ in $\mathrm{CO}$ ), and that sulfur is fully converted in $\mathrm{SO}_{2}$, hydrogen in $\mathrm{H}_{2} \mathrm{O}$, and nitrogen in $\mathrm{N}_{2}$, the overall equation for combustion of $100 \mathrm{~kg}$ of Eucalyptus gender, in air $\left(3.76 \mathrm{O}_{2}+\mathrm{N}_{2}\right)$, is expressed by the following Eq.09, according to Joshi et al. (1989) and Zhang et al. (1999):

$3.49 \mathrm{C}+5.03 \mathrm{H}+2.35 \mathrm{O}+0.018 \mathrm{~N}+0.00026 \mathrm{~S}+1.66 \mathrm{H}_{2} \mathrm{O}+$

$0.617+3.40\left(\mathrm{O}_{2}+3.76 \mathrm{~N}_{2}\right)+3.14 \mathrm{CO}_{2}+0.350 \mathrm{CO}+$

$0.00026 \mathrm{SO}_{2}+2.51 \mathrm{H}_{2} \mathrm{O}+12.81 \mathrm{~N}_{2}+1.66 \mathrm{H}_{2} \mathrm{O}+12.81 \mathrm{~N}_{2}+$

$1.66 \mathrm{H}_{2} \mathrm{O}+0.617$

In statistical analysis, the influence of the fuel wood type in the response variables of interest was evaluated using analysis of variance (ANOVA) of Kruskal-Wallis (nonparametric) and stepwise multiple comparisons of StudentNewman-Keuls, with the support of the software BioEstat version 5.0. The significance level $(\alpha)$ for ANOVA was 5\% and the null hypothesis $\left(\mathrm{H}_{0}\right)$ formulated was the equivalence of means, implying the non-equivalence between means for the alternative hypothesis $\left(\mathrm{H}_{1}\right)$. Additionally, through this statistical analysis, the energy efficiency data from this study were compared with the results investigated by Lau et al. (2013), where three models of residential and traditional cook stoves were evaluated. The investigated responses by ANOVA were efficiency, power, burned mass, and released gases from combustion $\left(\mathrm{CO}_{2}, \mathrm{SO}_{2}\right.$ and $\left.\mathrm{CO}\right)$ for five samples per variable.

\section{RESULTS}

The Table 2 presents the energetic properties and gas quantity released by the improved cook stove. The cook stove efficiency and thermal power depends on the eucalyptus specie used in the combustion, where higher efficiency is followed by a tendency to decrease the quantity of burning wood. However, the statistical analyses from Table 3 shows that, except for Eucalyptus camaldulensis, there is no significate correlation between the efficiency and the fuelwood specie using to produce heat energy.

Table 2. Results of the obtained variables for each Eucalyptus sp. used as fuelwood in the cook stove.

Tabela2. Resultados das propriedades obtidas para cada lenha de eucalipto usado como combustível no fogão à lenha.

\begin{tabular}{ccccccc}
\hline $\mathrm{A}$ & $\mathrm{Ef}(\%)$ & $\mathrm{Pf}(\mathrm{W})$ & $\mathrm{m}_{\mathrm{q}}(\mathrm{kg})$ & $\mathrm{CO}_{2}\left(\mathrm{Nm}^{3} / \mathrm{kg}\right)$ & $\mathrm{CO}\left(\mathrm{Nm}^{3} / \mathrm{kg}\right)$ & $\mathrm{SO}_{2}\left(\mathrm{Nm}^{3} / \mathrm{kg}\right)$ \\
\hline & $9.8 \pm 1.3$ & $127.6 \pm 12.2$ & $0.1 \pm 0.0$ & $0.2 \pm 0.0$ & $0.02 \pm 0.0$ & $1.5 \times 10^{-5} \pm 0$ \\
2 & $8.7 \pm 1.0$ & $140.6 \pm 18.4$ & $0.1 \pm 0.0$ & $0.2 \pm 0.0$ & $0.02 \pm 0.0$ & $1.5 \times 10^{-5} \pm 0$ \\
3 & $8.7 \pm 0.5$ & $163.9 \pm 21.5$ & $0.1 \pm 0.0$ & $0.2 \pm 0.0$ & $0.02 \pm 0.0$ & $1.5 \times 10^{-5} \pm 0$ \\
4 & $10.4 \pm 2.0$ & $326.0 \pm 54.4$ & $0.2 \pm 0.0$ & $0.2 \pm 0.0$ & $0.02 \pm 0.0$ & $1.4 \times 10^{-5} \pm 0$ \\
5 & $4.2 \pm 0.8$ & $175.5 \pm 35.6$ & $0.3 \pm 0.0$ & $0.2 \pm 0.0$ & $0.03 \pm 0.0$ & $2.0 \times 10^{-5} \pm 0$ \\
6 & $3.5 \pm 0.7$ & $181.3 \pm 49.7$ & $0.4 \pm 0.1$ & $0.3 \pm 0.1$ & $0.03 \pm 0.0$ & $7.4 \times 10^{-5} \pm 0$ \\
7 & $8.5 \pm 0.6$ & $131.5 \pm 19.8$ & $0.1 \pm 0.0$ & $0.2 \pm 0.0$ & $0.02 \pm 0.0$ & $1.5 \times 10^{-5} \pm 0$ \\
8 & $6.8 \pm 1.0$ & $116.5 \pm 24.1$ & $0.1 \pm 0.0$ & $0.2 \pm 0.0$ & $0.02 \pm 0.0$ & $1.5 \times 10^{-5} \pm 0$ \\
9 & $7.0 \pm 1.2$ & $94.1 \pm 49.9$ & $0.1 \pm 0.0$ & $0.2 \pm 0.0$ & $0.02 \pm 0.0$ & $1.5 \times 10^{-5} \pm 0$ \\
\hline
\end{tabular}

A: Species; Ef: Efficiency; $\mathrm{m}_{\mathrm{q}}$ : mass of fuel consumed in water heating; $\mathrm{CO}_{2}$ : carbon dioxide content; $\mathrm{CO}$ : carbon monoxide content; $\mathrm{SO}_{2}$ : sulfur dioxide content; 1: Eucalyptus propinqua; 2: Eucalyptus urograndis; 3: Eucalyptus grandis; 4: Eucalyptus saligna; 5: Corymbia citriodora; 6: Eucalyptus urophylla; 7: Eucalyptus pellita; 8: Eucalyptus camaldulensis; 9: Eucalyptus tereticornis.

Table 3 presents the results for the analysis of variance according to Kruskal-Wallis test for the different fuelwood species, and the results of the stepwise multiple comparisons of Student-Newman-Keuls. Similar letters imply in treatments with means statistically equivalent.

The quantity of burning wood in the combustion chamber depends on the fuel wood species, where E. grandis, E. saligna, Corymbia citriodora and E. urophylla produce about twice higher quantity of burning wood than the others. The statistical analyses indicate that the different behavior among the fuel wood species, in the combustion reactions, do not affect directly the efficiency of the cook stove, however the thermal power increase significantly for the Eucalyptus species that produce a higher quantity of burning wood, Table 3.

The statistical analysis also shows that the difference in volume of released gases during combustion $\left(\mathrm{SO}_{2}, \mathrm{CO}_{2}\right.$ and $\mathrm{CO}$ ) among all species studied here are not significant, providing equivalent values independent of the fuel wood used, with a $\mathrm{CO}_{2}$ volume about ten times higher than $\mathrm{CO}$ gas. Fuel eucalyptus wood presents only traces of $\mathrm{SO}_{2}$ gas.

Traditional cook stoves from Lau et al. (2013) research have twice lower energy efficiency (Ref 1: $2.9 \% \pm 0.3$; Ref 2: $2.6 \% \pm 0.5$; Ref $3: 4.6 \% \pm 0.2)$ than the improved one presents in our study (p-value $<0.05)$, Table 4 . 
Table 3. Results of statistical analysis of Kruskal-Wallis and Student-Newman-Keuls.

Tabela3. Resultados da análise estatística de Kruskal-Wallis e Student-Newman-Keuls.

\begin{tabular}{|c|c|c|c|c|c|c|}
\hline Responses & Efficiency & Burned mass & Power & Volume $\mathrm{CO}_{2}$ & Volume $\mathrm{SO}_{2}$ & Volume $\mathrm{CO}$ \\
\hline P-value & 0.003 & 0.000 & 0.000 & 0.779 & 0.763 & 0.752 \\
\hline 1 & $\mathrm{ABC}$ & $\mathrm{D}$ & $\mathrm{C}$ & $A$ & $A$ & $A$ \\
\hline 2 & $\mathrm{ABC}$ & $\mathrm{D}$ & $C$ & $A$ & $A$ & $A$ \\
\hline 3 & $\mathrm{ABC}$ & $\mathrm{BCD}$ & $A B C$ & $A$ & $A$ & $A$ \\
\hline 4 & A & A & $A$ & $A$ & $A$ & $A$ \\
\hline 5 & $\mathrm{AB}$ & $\mathrm{BC}$ & $B$ & $A$ & $A$ & $A$ \\
\hline 6 & $\mathrm{AB}$ & $\mathrm{AB}$ & $A$ & $A$ & $A$ & $A$ \\
\hline 7 & $\mathrm{ABC}$ & $\mathrm{D}$ & $C$ & $A$ & $A$ & $A$ \\
\hline 8 & $\mathrm{C}$ & $\mathrm{D}$ & $C$ & $A$ & $A$ & $A$ \\
\hline 9 & $\mathrm{BC}$ & $\mathrm{D}$ & $C$ & $A$ & $A$ & $A$ \\
\hline
\end{tabular}

1: Eucalyptus propinqua; 2: Eucalyptus urograndis; 3: Eucalyptus grandis; 4: Eucalyptus saligna; 5: Corymbia citriodora; 6: Eucalyptus urophylla; 7: Eucalyptus pellita; 8: Eucalyptus camaldulensis; 9: Eucalyptus tereticornis.

Table 4. Results of statistical analysis of Kruskal-Wallis and StudentNewman-Keuls with the grouping by efficiency of stove.

Tabela 4. Resultados da análise estatística de Kruskal-Wallis e Student-Newman-Keuls com o agrupamento por eficiência do fogão.

\begin{tabular}{ccccccc}
\hline Species & DF & $p$-value & Eucaliptus & Ref & Ref & Ref \\
\hline 1 & 3 & 0.0009 & A & C & C & B \\
2 & 3 & 0.0009 & A & C & C & B \\
3 & 3 & 0.0009 & A & C & C & B \\
4 & 3 & 0.0009 & A & BC & C & B \\
5 & 3 & 0.0009 & A & B & B & B \\
6 & 3 & 0.0009 & A & C & C & B \\
7 & 3 & 0.0009 & A & C & C & B \\
8 & 3 & 0.0009 & A & C & C & B \\
9 & 3 & 0.0009 & A & C & C & B \\
\hline
\end{tabular}

DF: degrees of freedom; 1: Eucalyptus propinqua; 2: Eucalyptus urograndis; 3: Eucalyptus grandis; 4: Eucalyptus saligna; 5: Corymbia citriodora; 6: Eucalyptus urophylla; 7: Eucalyptus pellita; 8: Eucalyptus camaldulensis; 9: Eucalyptus tereticornis.

\section{DISCUSSION}

Improved cook stove using rocket stove technology is also called "fuel saving stove" or "fogão poupa-lenha" in Portuguese language. In traditional cook stoves, during the combustion of fuelwood, the heat usually is diffusely released. In contrast, in rocket stoves there is a heat concentration in a single direction, which requires in the preparation and cooking of food, using less fuelwood than traditional stoves. In the improved cook stove, the combustion chamber is thermally insulated, which results in a lower heat loss to the metal walls area, better mixture of fuel and oxygen, as well as, a better channeling of volatiles from burning process. In summary, its operation is based on the heat concentration in the combustion chamber (McCracken and Smith, 1998).

Comparing our study to the traditional cook stove of Lau et al. (2013), we note that despite the existence of gas stoves inside the household kitchens, it is observed that the population from Irati city, in Paraná state, especially those that lives in remote and rural areas, still makes a frequent and significant use of traditional cook stoves.

Our result indicates a potential risk to the cook stove user's health, due to the release of toxic $\mathrm{CO}$ gas in the smoke from the burning process, because of that the cook stove cannot be used without a chimney inside the household kitchens. Gas of released $\mathrm{CO}_{2}$ from fuelwood is less polluting than fossil fuel because $\mathrm{CO}_{2}$ is consumed by trees' wood during photosynthesis process. Another advantage of the eucalyptus biomass from planted forest is its low sulfur content that provides a decrease of the sulfuric acid formation in the environment (Joshi et al, 1989).

About the cook stove proposed to other researchers in the world, the energetic performance of an improved cook stoves used in Guatemala has $13.7 \%$ efficiency, which is similar to that found in our research (McCracken; Smith, 1998) However, it is not possible to compare directly our results because the energetic efficiency was measured using the methodology named Water Boiling Test (WBT) method, different from our study. Damark (2009) also reported that cook stoves available in Ghana have thermal efficiency from 8 to $15 \%$, using charcoal as fuel with improve the quantity of toxic $\mathrm{CO}$ gas during fuel burning. In the study presented by Ballard-Tremeer; Jawurek (1996) the efficiency of an improved stove achieves $21 \%$, presenting the highest energy efficiency than other and our studies, although there is no much information about the technology used to build this cook stove.

The reference-stoves from the study of Lau et al. (2013) have about twice lower thermal efficiency in the use of fuel, due to the heat loss through the metal walls without thermal isolation. Therefore, the isolation of the combustion chamber in the proposed prototype ensured a better use of useful energy, with a good potential for practical applications.

\section{CONCLUSIONS}

Although the nine varieties of Eucalyptus species investigated in this research have no significant influence on the thermal efficiency of the improved cook stove, Eucalyptus gender proved to be an appropriate fuelwood biomass for this purpose, due to the higher energy efficiency of the improved cook stove than traditional one, proving its energy and environmental advantages due to the fuelwood comes from planted forest.

Most methods for evaluation of firewood stoves are based only on the thermal performance of the equipment, ignoring the pollutant emissions. However, these stoves release large amounts of volatile and toxic gases, which are harmful to the user's health. Our improved cook stove release toxic $\mathrm{CO}$ gas and traces of $\mathrm{SO}_{2}$ gas.

The prototype showed higher performance when compared with traditional stoves in Brazil, and a similar performance when compared to other countries, evidenced by the low cost and of its easy construction and use practicality. Furthermore, has been proved that the prototype is an alternative that integrates social, economic and sustainable improvements 
when compared to the traditional stoves that uses wood charcoal to energy production.

\section{ACKNOWLEDGMENTS}

To students of Forest Engineering of UNICENTRO, Carla Fernanda Mussio, Emilio Carlos Zilli Ruiz and Ricardo Moreira Cordoni for the collaboration in the early stages of our research.

\section{REFERENCES}

BALLARD-TREMEER, G.; JAWUREK, H. H. Comparison of five rural, wood-burning cooking devices: efficiencies and emissions. Biomass and Bioenergy, Oxford, v. 11, n. 5, p. 419-430, 1996. https://dx.doi.org/10.1016/S0961-9534(96)00040-2

BORGES, T. P. F. Fogão a lenha de combustão limpa. 1994. 121f. Dissertação (Mestrado) - Universidade Estadual de Campinas, Campinas, Brazil, 1994.

BRAND, M. A. Energia de biomassa florestal. Rio de Janeiro: Interciência, 2010. 114 p.

BRAND, M. A.; MUÑIZ, G. I. B.; BRITO, J. O.; QUIRINO, W. F. Influência das dimensões da biomassa estocada de Pinus taeda L. e Eucalyptus dunnii Maiden na qualidade do combustível para geração de energia. Revista Árvore, Viçosa, v. 38, n. 1, p. 175-183, 2014. DOI: http://dx.doi.org/10.1590/S0100-67622014000100017

BRITO, J. O. O uso energético da madeira. Estudos Avançados, São Paulo, v. 21, n. 59, p. 185-193, 2007. DOI: 40142007000100015

BRITO, J. O.; CINTRA, T. C. Madeira para energia no Brasil: realidade, visão estratégica e demanda de ações. Biomassa \& Energia, v. 1, n. 2, p. 157-163, 2004.

CASH, D. W.; CLARK, W. C.; ALCOCK, F.; DICKSON, N. M.; ECKLEY, N.; GUSTON, D. H.; JÄGER, J.; MITCHELL, R. B. Knowledge systems for sustainable development. Proceedings of the National Academy of Sciences of the United States of America (PNAS), Washington, v. 100, n. 14, p. 8086-8091, 2003. DOI: https://dx.doi.org/10.1073/pnas.1231332100

CASTRO, L. R.; CORTEZ, L. A. B. Influência da temperatura no desempenho de biodigestores com esterco bovino. Revista Brasileira de Engenharia Agrícola Ambiental, Campina Grande, v. 2, n. 1, p. 97-102, 1998. DOI: http://dx.doi.org/10.1590/1807-1929/agriambi.v2n1p97102

CORTEZ, L. A. B.; LORA, E. E. S.; GÓMEZ, E. O. Biomassa para energia. Campinas: Unicamp, 2009. 735 p.

DANMARK, C. A. R. E. Pre-feasibility study for an improved cook stoves project in Northern Ghana. Energica, 2009. 65 p.

DOAT, J. Le pouvoir calorifique des bois tropicaux. Boiset Forêts des Tropiques. n. 172, p. 33-55, 1977.

EPE_EMPRESA DE PESQUISA ENERGÉTICA. Balanço Energético Nacional 2018: Ano base 2017. 2018. Disponível em: <http://www.epe.gov.br/pt/publicacoesdados-abertos/publicacoes/balanco-energetico-nacional2018>. Acesso em 17 de abril de 2019.

GABRIELLE, B.; THE, N. N.; MAUPU, P.; VIAL, E. Life cycle assessment of eucalyptus short rotation coppices for bioenergy production in southern France. GCB
Bioenergy, v. 5, n. 1, p. 30-42, 2013. DOI: https://dx.doi.org/10.1111/gcbb.12008

JOSHI, V.; VENKATARAMAN, C.; AHUJA, D. R. Emissions from burning biofuels in metal cookstoves. Environmental Management, New York, v. 13, n. 6, p. 763-772 1989.

DOI: https://dx.doi.org/10.1007/BF01868315

KIDANU, S.; MAMO, T.; STROOSNIJDER, L. Biomass production of Eucalyptus boundary plantations and their effect on crop productivity on Ethiopian highland Vertisols. Agroforestry Systems, Dordrecht,v. 63, n. 3, p. 281-290. DOI: https://dx.doi.org/10.1007/s10457-0055169-Z

LAU, P. C.; MACHADO, G. O.; NOGUEIRA, L. A. H; CHRISTOFORO, A. L.; GONÇALVES, D.; LAHR, F. A. R. Evaluation of the efficiency energy of wood stove from Irati Brazilian city. International Journal of Agriculture and Forestry, v. 3, n. 7. p. 267-272, 2013.

MACHADO, G. O.; CHRISTOFORO, A. L.; BERTOLINI, M. S.; DINIZ, C. C. C.; SILVA, F. N.; SZEKUT, F. P.; MATOS, F. G. Avaliação da qualidade energética e ambiental de fogão à lenha portátil para a cidade de Irati/Pr. Journal of Biotechnology and Biodiversity. v. 5, n. 2, p. 182-193, 2014. DOI: https://dx.doi.org/10.19180/1809-2667.v17n315-06

MCCRACKEN, J. P.; SMITH, K. R. Emissions and efficiency of improved woodburning cookstoves in Highland Gatemala. Environment International, New York, v. 24, n. $7, \quad$ p. 739-747, 1998 . DOI: https://dx.doi.org/10.1016/S0160-4120(98)00062-2

MÜllER, M. D.; COUTO, L.; LEITE, H. G.; BRITO, J. O. Avaliação de um clone de eucalipto estabelecido em diferentes densidades de plantio para produção de biomassa e energia. Biomassa \& Energia, v. 2, n. 3, p. 177-186, 2005.

NOGUEIRA, L. A. H.; LORA, E. E. S. Dendroenergia: fundamentos e aplicações. Rio de Janeiro: Interciencia, 2003. $200 \mathrm{p}$.

NORTHCROSS, A. L.; HAMMOND, S. K.; CANUZ, E.; SMITH, K. R. Dioxin inhalation doses from wood combustion in indoor cookfires. Atmospheric Environment, Oxford, v. 49, n. 2012, p. 415-418, 2012. DOI: https://doi.org/10.1016/j.atmosenv.2011.11.054

NOSEK, R.; HOLUBCIK, M.; JANDACKA, J. The impacts of bark content of wood biomass on biofuel properties. BioResources. Raleigh, v. 11, n. 1, p. 44-53. DOI: https://dx.doi.org/10.15376/biores.11.1.44-53

PARIKH, J.; CHANNIWALA, S. A.; GHOSAL, G. K. A correlation for calculating HHV from proximate analysis of solid fuels. Fuel, London, v. 84, n. 5, p. 487-494, 2005. DOI: https://dx.doi.org/10.1016/j.fuel.2004.10.010

ROCKWOOD, D. L.; RUDIE, A. W.; RALPH, S. A.; ZHU, J. Y.; WINANDY, J. E. Energy product options for eucalyptus species grown as short rotation woody crops. International Journal of Molecular Sciences. v. 9, n. 8, p. $1381-1378$

2008. DOI: https://dx.doi.org/10.3390/ijms9081361

ROSILLO-CALLE, F.; BAJAY, S.; ROTHMAN, H. Uso da biomassa para produção de energia na indústria brasileira. Campinas, Unicamp, 2005. 448 p.

SANTOS, R. C.; CARNEIRO, A. C. O.; TRUGILHO, P. F.; MENDES, L. M.; CARVALHO, A. M. M. L. Análise termogravimétrica em clones de eucalipto como subsídio 
para a produção de carvão vegetal. Cerne, Lavras, v. 18, n. $1, \quad$ p. $143-151, \quad 2012$ DOI: http://dx.doi.org/10.1590/S0104-77602012000100017

SCARLAT, N.; DALLEMAND, J. F.; SKJELHAUGEN, O. J.; ASPLUND, D.; NESHEIM, L.; An overview of the biomass resource potential of Norway for bioenergy use. Renewable and Sustainable Energy Reviews, v. 15, n. 7, p. 3388-3398, 2011. DOI: https://dx.doi.org/10.1016/j.rser.2011.04.028

SEIXAS, F.; COUTO, L.; RUMMER, R. B. Colheita de plantios arbóreos de curta rotação para energia. Biomassa \& Energia, v. 3, n. 1, p. 1-16, 2006.

SOUZA, O.; SCHULZ, M. A.; FISCHER, G. A. A.; WAGNER, T. M.; SELLIN, N. Energia alternativa de biomassa: bioetanol a partir da casca e da polpa de banana. Revista Brasileira de Engenharia Agrícola Ambiental. Campina Grande, v. 16, n. 8, p. 915-921, 2012. DOI: http://dx.doi.org/10.1590/S1415-43662012000800015

TUME - TESTE DE USO MÚLTIPLO DE EUCALIPTOS.

TUME. 2010. Disponível em:
http://www.ipef.br/eventos/2010/eucaliptocultura/06TUME.pdf. Acesso em 22 de fevereiro de 2016.

ZHANG, J.; SMITH, K. R.; UMA, R.; MA, Y.; KISHORE, V. V. N.; LATA, K.; KHALIL, M. A. K.; RASMUSSEN, R. A.; THORNELOE, S. T. Carbon monoxide from cookstoves in developing countries: 1. Emission factors. Chemosphere: Global Change Science, v. 1, n. 1-3, p.353-366, 1999. DOI: https://doi.org/10.1016/S14659972(99)00004-5

ZANUNCIO, A. J. V.; MONTEIRO, T. C.; LIMA, J. T.; ANDRADE, H. B.; CARVALHO, A. G. Drying biomass for energy use of Eucalyptus urophylla and Corymbia citriodora logs. BioResources, Raleigh, v. 8, n. 4, p. 5159 5168, 2013. 